\title{
Hâkimiyet-i Millîye Gazetesine Göre Maraş'ın Fransızlarca İşgali Ve Ermeni Mezalimi ${ }^{1}$
}

\author{
Meral KUZGUN \\ Dr. Öğr. Üyesi, Kilis 7 Aralık Üniversitesi, Muallim Rıfat Eğitim Fakültesi, \\ Sosyal Bilgiler Eğitimi Ana Bilim Dalı \\ meralkuzgun@kilis.edu.tr \\ Orcid ID: https://orcid.org/0000-0003-1314-0128
}

\section{Öz}

Osmanlı Devleti, Balkan Savaşlarının hemen arkasından Birinci Dünya Savaşı'na girmiş, birçok cephede savaşmış ancak savaştan yenik çıkmıştır. 29 Eylül 1918 tarihinde Bulgaristan'ın, İtilaf güçleriyle mütareke imzalamasıyla Osmanlı Devleti, Batı'dan istilaya açık hale gelmiştir. Talat Paşa Hükümeti'nin 7 Ekim 1918'de istifası üzerine yerine Ahmet İzzet Paşa Kabinesi kurulmuştur.

30 Ekim 1918 tarihinde imzalanan Mondros Mütarekesi'nin 7. maddesi bahane edilerek Anadolu'nun güney bölgesinin İtilaf devletlerince işgal edilmesi büyük bir halk direnişin ortaya çıkmasına neden olmuştur. Bölge önce İngilizlerin işgaline uğramış, daha sonrasında 17 Eylül 1919 tarihli "Suriye Antlaşması" ile Maraş'a dâhil edilmek üzere Fransa'ya bırakılmıştır. Böylelikle 31 Ekim 1919'da Maraş'1 işgal eden Fransızlar şehirde yaşayan Ermenilerle birlikte hareket etmiş̧lerdir. Bu nedenle Maraş halk1, 20 Ocak 1920'den 11 Şubat 1920'ye kadar yaşadıkları şehri kahramanca savunmuşlardır.

$\mathrm{Bu}$ makalede, Maraş’taki Fransız işgali ve Ermeni mezalimi hakkında Hâkimiyet-i Milliye Gazetesi'nin yaklaşımları ele alınarak, sonuç bölümünde Fransızların bölgeyi tahliye etmelerinin nedenleri ve söz konusu gazetenin Maraş savunmasına katkısı ile halkın genel tutumu değerlendirilmiştir.

Anahtar Kelimeler: Hâkimiyet-i Milliye, Maraş, Fransa, Ermeni Mezalimi, Kuvâ-yı Milliye.

\footnotetext{
${ }^{1}$ Makale Geliş/Kabul Tarihi: 13.12.2019 / 27.03.2020

Künye Bilgisi: Kuzgun, M. (2020). Hâkimiyet-i Milliye Gazetesine Göre Maraş'ın Fransızlarca İsgali Ve Ermeni Mezalimi. Kahramanmaraş Sütçü İmam Üniversitesi Sosyal Bilimler Dergisi, 17 (Özel Sayl), 186-201. DOI: 10.33437/ksusbd.658942
} 


\title{
French Occupation of Marash and the Armenian Atrocities Based on the Hâkimiyet-i Milliye Newspaper
}

\begin{abstract}
Ottoman State, immediately after Balkan War, went to the First World War and fought in many fronts but was defeated consequently. On September 29, 1918 as a result of the treaty signed between Bulgaria and the Entente states, Ottoman State was exposed to an invasion from the west. After resigning of Cabinet of Talat Pasha on October 7, 1918, Cabinet of Ahmed Izzet Pasha was formed.

The occupation of the southern part of Anatolia by the Entente states on the pretext of Article 7 of the Armistice of Mudros resulted in great civil resistance. The region was first occupied by the British, and then it was left to France, including the southern region of Marash, under the "Syrian Treaty" dated September 17, 1919. Thus, the French entered Marash on October 31, 1919. The clashes in Marash between January 20, 1920 and February 11, 1920 caused by the French-Armenian cooperation led to the heroic struggle of the Marash people.

This paper will discuss the approaches of the Hâkimiyet-i Milliye (National Sovereignty) Newspaper to the French invasion and Armenian atrocity in Marash, where the conclusion will review why the French evacuated the region and the contribution of the newspaper to the defense of Marash and the general public attitude.
\end{abstract}

Keywords: Hâkimiyet-i Milliye, Marash, France, Armenian Atrocity, Kuvây1 Milliye

\section{GİRIŞ}

Osmanlın Devleti, Balkan Savaşlarındaki yenilginin etkisi ile ordu ve donanmasını sslah etme işlerine girişirken, bir yandan da iki bloka ayrılmış Avrupa'da kendisini yalnızlıktan kurtarmak için birtakım ittifak teşebbüslerinde bulunmuştur. Osmanlı Devleti'nin İtilaf Devletleri blokuna katılmak için yaptığı tüm girişimler sonuçsuz kaldığından Osmanlı Devleti ister istemez Birinci Dünya Savaşı'nda kendini Almanya'nın yanında bulmuştur (Armaoğlu, 2007:107-108).

Birinci Dünya Savaşı, doğu ve batı cephesi olmak üzere iki genel cephede açılmıştır. Doğu Cephesi’nde açılan savaşın içinde yer alan Osmanlı Devleti, 


\section{KSÜSBD Milli Mücadelenin 100. Yılında Kahramanmaraș Özel Sayısı}

Kafkas, Irak, Suriye-Filistin, Hicaz-Yemen, İran, Libya, Çanakkale ve GaliçyaRomanya-Makedonya cepheleri olmak üzere on cephede savaşmıştır (Mütercimler,2010: 3-4).

Birinci Dünya Savaşı sırasında Türk topraklarının işgaline imkân sunan ve Ekim 1916 yılında imzalanan Sykes-Picot Antlaşması, Ortadoğu'yu beş bölgeye ayırmıştır. Buna göre Adana, Antakya bölgesi ile Suriye kıyıları ve Lübnan toprakları Mavi bölge olarak Fransa’ya, Musul hariç olmak üzere Irak yani Kırmızı bölge olarak tanımlanan Fırat ve Dicle nehirleri arasında kalan topraklar İngiltere'ye verilmiştir. Bu bölgelerin dışında kalan Arap topraklarında Büyük Arap Krallığ kurulmakla birlikte bu krallıkta A Bölgesi Suriye'nin artan bölgeleri ile Musul Fransız, B Bölgesi Ürdün, İngiliz denetiminde bulunacaktır. Beşinci bölge olan Filistin'de ise uluslararası bir yönetimin kurulması amaçlanmıştır (Özkan, 2015: 133).

1918 Eylül ayında başlayan İtilaf saldırısı ile Osmanlı Devleti'nin müttefiki Bulgaristan 29 Eylül'de imzaladığı mütareke ile savaş dışı kalmıştır. Bu gelişmenin ardından 4 Ekim günü Osmanlı Devleti, ABD'ye bir nota vermiştir. Osmanlı Hükümeti'nin vermiş olduğu notada, ABD başkanı Wilson'un 8 Ocak 1918 tarihli 14 prensibine uygun olarak mütareke ve sulh görüşmelerine hazır olunduğu belirtilmiştir (Özkan, 2016: 23-24). Bu teklifin ardından 7 Ekim’de Sadrazam Talat Paşa yeni kurulacak bir hükümetle barış görüşmelerinden daha iyi bir sonuç alınabileceği düşüncesinde olduğundan istifa etmiştir. $\mathrm{Bu}$ olayı takiben, başa gelen Ahmet İzzet Paşa Kabinesi (Turan, 2008: 168) mütareke meselesi üzerinde durmaya başlamışıı. ABD başkanı Wilson; İngiltere, Fransa ve İtalya ile yaptığı temaslar neticesinde 24 Ekim'de Osmanlı Devleti'ne olumlu cevap vermiştir. Buna göre Sulh 'un, Wilson'un ortaya koyduğu ilkeler doğrultusunda yapılacağı belirtilmiştir (Özkan, 2016: 23-25).

$\mathrm{Bu}$ gelişmelerin 1şı̆̆ında, Osmanlı Devleti, 30 Ekim 1918'de itilaf devletleriyle Mondros Mütarekesi İmzalamıştır. Söz konusu Mütareke İstanbul hükümetinin orduların terhis edilmesine ve galiplerin her dediğine boyun eğmesine neden olmuştur. Müttefikler, Mütareke'nin 7. maddesiyle Doğu Anadolu bölgesini, 24. maddesiyle de bütün Osmanlı toprağını işgal edebilme hakkını elde etmişlerdir (Oran, 2009: 110-111). Mütarekenin ardından Mustafa Kemal Paşa, 5 Kasım 1918 tarihinde Adana'da Ali Fuat Paşa'ya milletin kendi hakkını araması gerektiğini ve kendilerinin de millete yardım etmeleri gerektiğini belirtmiştir (Hatipoğlu, 2001: 30-31).

\section{Mondros Mütarekesi Sonrası Maraş}

Mondros Mütarekesi'nin imzalanmasından sonra Osmanlı toprakları İtilaf kuvvetlerince işgal edilmeye başlanmıştır. İşgal edilen yerlere asayişi sağlama 
bahanesiyle giren İtilaf kuvvetleri, halkın dini ve milli duygularıyla oynamıştır (Hâkimiyet-i Milliye, 3 Mart 1336:3).

İngilizler, Sykes-Picot Antlaşması ile Fransa'ya bırakılan ve petrol sahası olan Musul ile Urfa, Maraş, Birecik ve Antep'i işgal etmeyi tasarlamışlardır. Mütarekenin 7. maddesini işgal amaçları doğrultusunda kullanan İngilizler, 3 Kasım 1918 tarihinde Musul'u işgal ettiler(Doğan,2011: 1440). Daha sonrasında Halep üzerinden Kilis'e oradan da Antep ve Carablus' a gelen İngilizler, (Doğan, 2004: 161) Maraş'ı 22 Şubat 1919 tarihinde işgal etmiş ve şehirdeki Ermeniler ise bu işgali sevinçle karşılamışlardır. İngilizler, Amerikan Kolejini karargâh olarak kullanmakla birlikte sevk ve iskân kanunu sırasında Maraş’tan gönderilen Ermenileri kollayarak şehre geri dönmelerini sağlamışlardır. Ermenilerin, Türklere yönelik artan çirkin hareketlerine karşı başta ses çıkarmayan İngilizler, Türklerin karşılık vermesinden çekindikleri için tedbir almaya başlamışlardır. Musul'un kendilerine verilmesini ve Filistin bölgesinin de kendi nüfus sahası olarak tanınmasını isteyen İngiltere, bu amacına ulaşmak için Maraş ile birlikte işgal ettiği diğer komşu vilayetleri Fransızlara karşı bir koz olarak kullanmak istemiştir (Büyükoğlu, 2012: 27-31).

İngilizler, işgalleri süresince Maraş'1 Türklerin çok iyi savunacaklarını düşündüklerinden Fransızları, sonuç alamayacakları bir alanda meşgul ederek dikkatlerini Ortadoğu topraklarından uzak tutmayı planlamışlardır. Bu sayede İngilizlerin Maraş’taki kuvvetleri büyük ölçüde serbest kalabilecekti (Doğan, 2008: 252).

Maraş'ın, İngiltere ve Fransa tarafindan işgal edilmesinde sahip olduğu coğrafi konumu da oldukça etkili olmuştur. Maraş, doğu Toroslarda üç stratejik geçide yakınlığı nedeniyle önemlidir. Bunlardan bir tanesi Göksun, Elbistan ve Yarpuz ile Malatya'dır. Bunun yanı sıra Maraş'ın, ticaret güzergâhı üzerinde olması ve bölgede var olan Alman yapımı demiryolunun Maraş'1 İslâhiye'ye oradan da Bağdat'ta bağlaması bölge açısından oldukça dikkate değerdir (The Armenian Review, Vol: 30, No: 4-120, Winter, 1977-78: 383).

Maraş'ın İngilizlerce işgali sekiz ay sürmüştür. Bu süre içinde İngilizlerin Ermenilerin taşkınlıkları ve tahrikleri karşısında takındıkları yansız tavır olayların çıkmasını önlemiştir (Ünalp, 2018: 209). Sekiz aylık İngiliz işgalinden sonra her ne kadar Sykes-Picot Anlaşması gereğince Maraş ve diğer güney vilayetleri Fransız menfaat alanı olarak belirlenmişse de 17 Eylül 1919'da İngiltere ve Fransa arasında "Suriye Anlaşması" adını taşıyan bir anlaşma imzalanmıştır. Buna göre İngiliz kuvvetleri, 1 Kasım 1919 tarihinden itibaren Kilikya ve Suriye'den çekilecek, Şam, Hama, Humus Arap devleti sınırları içinde kalacak, Sykes-Picot çizgisinin batısında kalan garnizonlar da Fransızlara teslim edilecektir (Özkan: 2015: 135). 


\section{KSÜSBD Milli Mücadelenin 100. Yılında Kahramanmaraș Özel Sayısı}

Bununla birlikte İtilaf devletleri, Türkiye'nin taksimine yol bulmak için Yunanlılara işgal ettirdikleri Batı Anadolu'da yaptırdıkları yok etme hareketlerini Ermeniler aracıllğı ile Anadolu'nun güneyinde de yapmak istemişlerdir. $\mathrm{Bu}$ durum, 4- 11 Eylül 1919 tarihleri arasında yapılan Sivas Kongresi ile ortaya çıkan Temsil Heyeti'nin de dikkatini çekmiş ve Güney Anadolu'nun teşkilatlanmasına yardım edilmesi için Binbaşı Kemal (Doğan), Yüzbaşı Osman (Tufan) ve Yüzbaşı Ratip (Sinan) Temsil Heyetince görevlendirilmiştir. Bütün işgal bölgesinin Fransızlara terk edilmesi hususundaki İngiliz-Fransız Anlaşmasını da Mustafa Kemal Paşa protesto etmiştir (İlter, 1995: 129-130). Tüm protestolara rağmen Fransız askerleri, 31 Ekim 1919'da Maraş'a girmiş̧ir. Fransız ordusunun en dikkat çeken yanı büyük bir çoğunluğunun Ermeni gönüllülerden oluşmasıdır (Akbıyık, 1999: 77).

İşgal sonrası Maraş halkını harekete geçiren ve "Bayrak Olayı" olarak anılan hadise oldukça önemlidir. Buna göre; Fransız İşgal Kumandanı Yüzbaşı Andre'ye 24 Kasım 1919 tarihinde Maraş'a gelmiş ve nüfuzlu Hırlekyan ailesinin evinde konaklamıştır. Akşam yemeğinden sonra Yüzbaşı, genç bayanlardan birine dans etmeyi teklif etmiş fakat teklifte bulunduğu genç kız "ne Fransız ne de Ermeni bayrağı olmayan bir şehirde dans etmek istemediğini” söylemiştir. $\mathrm{Bu}$ konuşmadan bir gün sonra 28 Kasım sabahı Türkler, kale üzerinde dalgalanan bir Fransız bayrağı görmüş ve öfkeli kalabalık tepeye tırmanmaya başlayarak Fransız bayrağı yerine Türk bayrağını asmıştır. Yüzbaşı Andre bu olaydan sonra Antep'e çağrılmış ve asla geri dönmemiştir (Armenian Rewiev, Vol. 30, No: 4-120, Winter 1977-78: 390).

Maraş halkını harekete geçiren bir başka olay da Fransızların Maraş'ı yeni işgal ettikleri sırada, 31 Ekim 1919 tarihinde, Fransızlardan cesaret alan Ermenilerin, Maraş sokaklarına dağılması ve önlerine gelen Türklere hakaret etmesiyle başlamıştır. Fransız askerleri ise bu duruma seyirci kalmıştır. Ermeni askerlerinden birisi hamamdan çıkan bir Türk kadınına saldırmış ve peçesini yırtmıştır. Söz konusu asker devamında "Artık burası Türklerin değildir. Fransız memleketinde peçe ile gezilmez" diyerek kadına saldırmış, olayı gören Maraşlılar, Ermenileri uyarmış ancak Ermeniler çirkin sözlerle karşılık verip silaha sarılmışlardır. Bu sırada olayı gören Sütçü İmam, tabancasını Ermeni askerlerine doğru ateşleyerek bir Ermeni askeri öldürmüş ve olay mahallinden uzaklaşmıştır. Silah sesleri üzerine henüz kenti terk etmemiş olan İngiliz askerleri de gelmiştir. Sütçü İmam olayından bir gün sonra da İngilizler Maraş’1 terk ederek Antep istikametine çekilmişlerdir (Ünalp, 2018: 215).

Ülkedeki işgaller ve Osmanlı hükümetinin tavrı üzerine Hâkimiyet-i Milliye Gazetesi'nin 24 Şubat 1920 tarihli “Kuvâ-yı Milliye'ye Ne Oluyor" başlıklı haberinde hükümet idaresinde ikilik olup olmadığı sorgulanmıştır. Bu soru üzerinden Kuvâ-yı Milliye'nin hangi şartlar altında teşekkül ettiğini ortaya 
koymaya çalışan gazete, Meşrutiyet devrinden itibaren hükümet görevlilerinin keyfi ve kanunsuz işler yaptıklarını ve bu halin, milleti çöküşe götürdüğüne, her yanlış iş neticesinde "Ne yapalım Ingilizler böyle istiyor!" teranelerine sığındıklarını belirtmiştir. Bu ihanetlerin neticesinde İzmir'in, Maraş'ın, Urfa'nın, Adana'nın işgal edildiği ve milletin kanının aktığına değinilmiştir. Yaşanan korkunç olaylar üzerine tahammülü biten Türk milletinin başkaldırısıyla Kuvâ-yı Milliye ruhunun doğduğuna dikkat çekilmiştir (Hâkimiyet-i Milliye, 24 Şubat 1336: 1).

$\mathrm{Bu}$ ruh Maraş'ta da kendini göstermiştir. Terhis edilmiş ve memleketin çeşitli yerlerine dağılmış, sayıları azaltılmış askeri birlikler, hangi olaya yardım edeceğini kestiremez hale gelmiş̧ir. Maraş bölgesinin idaresine verilen 3. Kolorduca bu bölgedeki teşkilatın kuvvetlenmesine çalışılıış ancak, bölgeye yalnızca subaylar gönderilebilmiş bunun ötesinde pek bir şey de yapılamamıştır. Çünkü 3. Kolordunun alayları Sivas, Amasya, Tokat, Samsun, Kavak ve Hamza' da bulunmakla birlikte bu çevredeki Pontus çetelerine karşı da bölgenin güvenliğini sağlamaya çalışmışlardır (Akbıyık, 1999: 170).

\section{Hâkimiyet-i Millîye Gazetesi'nin Fransız-Ermeni İşbirliğini Ele Alışı}

Hâkimiyet-i Milliye Gazetesi, 11 Eylül 1919'da Sivas Kongresi’nin sona ermesinden sonra 14 Eylül 1919'da yayın hayatına başlayan İrade-i Milliye gazetesinin devamı niteliğindedir. Mustafa Kemal Paşa, Sivas'tan Ankara'ya geçtikten sonra Ulusal Bağımsızlık Savaşı ile ilgili bilgileri içeren İrade-i Milliye Gazetesi, 18 Aralık 1919'daki sayısından itibaren Mustafa Kemal Paşa'nın doğrudan kontrolünde olmamıştır. O nedenledir ki, Mustafa Kemal Paşa'nın direktifiyle Ankara'da kurulan Hâkimiyet-i Milliye Gazetesi 10 Ocak 1920'de yayın hayatına başlamışı (Özkaya, 2007: 64-67).

Hâkimiyet-i Millîye Gazetesi Maraş ve çevresindeki Fransız işgali ile Ermeni mezalimine yer vererek kamuoyunu bilgilendirmeyi amaçlamış, zulüm ve haksızlıkların da sözcülüğünü yapmıştır. Bu noktadan hareketle Güney cephesinde Kuvâ-yı Milliye'nin teşekkülünden sonra Fransız-Ermeni işbirliği ile Maraş'ta 20 Ocak ve 10 Şubat 1920 tarihleri arasında yer alan işgali (İlter, 1995: 132) Hâkimiyet-i Milliye Gazetesine göre vermeye çalışacağız.

1920 Ocak ayı başından itibaren Maraş şehri içinde cereyan eden muharebelerin başlayacağ 1 ve 21 Ocak'a kadar olan sürede Maraş civarında Fransız kuvvetleri ile Kuvâ-yı Milliye grupları arasında da çarpışmalar yaşanmıştır. Bunlar sırasıyla; Eloğlu/Türkoğlu Çarpışması (5-7 Ocak 1920), Araplar Çarpışması (13 Ocak 1920), Harabe Çarpışmasıdır (19 Ocak 1920). Fransız kuvvetlerinin elinde yeterli miktarda haberleşme aracı bu sırada bulunmamıştır. O nedenle Binbaşı Roze Des Ordons, Türk haberleşme sistemi hakkında hazırladığı gizli raporu, Adana'da bulunan 3'üncü Fransız Tümeni 


\section{KSÜSBD Milli Mücadelenin 100. Yılında Kahramanmaraș Özel Sayısı}

Komutanı General Dufieux’a götürmek üzere bir kurye görevlendirmiştir. Ancak bu kurye, İslahiye yakınında Türkler tarafindan pusuya düşürülüp öldürülmüştür. Bu durum hiç şüphesiz Beyrut'tan telsiz teçhizatı göndermeyi ihmal eden Fransız subayların başarısızlı̆̆ının bir bedelidir (Ünalp, 2018: 218).

Fransız Kumandanı General Querette 13 Aralık 1919 tarihinde Maraş'ın güvenlik sorumluluğunu üzerine almış ancak asayişi sağlayamamıştır (Eyicil, 2015: 63). Bunun üzerine 25 Aralık 1919 tarihinde Kilis'te, Antep’te ve Urfa'da duvarlara General Querette ismini taşıyan broşürler yapıştırılmıştır. Bu broşürde “...Ayıntab, Maraş, Urfa sancaklarındaki Fransız kuvvetlerinin kumandasını deruhde ediyorum (Üstüme altyorum) ....namuslu olanlar Fransa tarafina iltizam etsinler (taraf tutma)" ibaresi yer almıştır. Böylelikle Anadolu'nun güneyindeki Fransız kuvvetlerinin başına General Querette'nin geçeceği ve halkın Fransa'nın yanında yer alıp direnişe geçilmemesi uyarısı yapılmışı ır (Hâkimiyet-i Millîye, 28 Kânunusani 1336: 3).

Hâkimiyet-i Millîye Gazetesi 10 Kânunusani 1336 (10 Ocak 1920) tarihli nüshasında "Adana ve Maraş Ahvali" başlığında Fransızların, Ermenilere karşı tavırlarını kısmen değiştirdikleri ve onlara karşı eskisi kadar ılımlı olmadıklarını belirtmiştir. Ancak, Kilikya bölgesinde Ermeni taşkınlıklarını Fransızların desteklediğini ifade eden gazete, Adana'da Kuvâ-yı Millîye teşkilatının propagandalarından dolayı Fransızlar tarafından şiddetin derecesinin özellikle Silifke ahalisine karşı arttığ belirtilmiştir. Haberinin devamında "Maraş Mutasarrlf Muavini olan Vahan isminde bir Ermeni'yi Maraşllar darp ve tard (kovma) etmişlerdir. Ahali kâmilen müsellahdır (silahlı). Hâkimiyetlerini muhafaza ve müdafaalar için fedakârlıkların en son derecesini göze almışlardır" dedikten sonra Kilis'te bulunan Fransız Kumandanının emriyle çoğunluğu Senegallilerden oluşan 2 bin kadar Fransız birliklerinin Mersin yolu üzerinden bölgeye nakillerinin yapıldığı notu düşülmüş ve birliklerdeki eksikliklerin yerli Ermenilerce giderildiği belirtilmiştir. Bunun yanı sıra, Adana'da 1.700, Mersin'de 3.000 kişilik, Antep, Maraş ve Urfa'da takriben 4.000 neferin olduğu ve bu kuvvetlerin karargâhının Katma olduğuna işaret edilmiştir. Gazete, Ermeni çetelerinin, işinde gücünde ticaretle meşgul olan insanların önlerinin para kopartılmak amacıyla kesildiğine dikkat çekerek “...Ermeni haydutların delaleti (rehberliği) ve medeni(!) Fransa hükümetinin memurları marifetiyle yapilan bu çirkin hareketin daha ne vakte kadar devam edeceği ve bilhassa hürriyet ve hukuk-u beşer namına bu kadar kan dökmüss olan Fransız milleti...”ş̧eklinde serzenişte bulmuştur (Hâkimiyet-i Milliye, 10 Kânunusani 1336: 4).

Fransızların saldırı hazırlıklarını tamamlaması üzerine Ermenilerle birlikte 20 kadar top, birçok makinalı tüfek ile ansızın Maraş şehri işgal edilmiştir. Bu işgalde Maraş ahalisinin katledilmeye başlanması üzerine halk, nefsi müdafaaya 
geçmiştir. İlk çarpışmalar 48 saat sürmüştür. Bu esnada Maraş halkına yardım etmek amacıyla çevre aşiretlerinde mücadeleye dâhil olmasıyla Suçatı, Ahır dağı, Ermeni mezarlığı ve Kayabaşı cihetinde Fransızlar ve Ermenilere karşı büyük bir mücadele verilmiştir. $\mathrm{Bu}$ hadiseden bir hafta öncesinde civar köylerde çarpışmaların başladığını belirten gazete, 13 Ocak 1920 tarihinde Antep'ten Maraş'a hareket eden 400 kişilik Ermeni ve Fransız kuvvetinin 6 mitralyöz ve 4 top ile Arapdar köyüne gece gelerek saldırdıklarını ve halkın dağlara kaçarak burada büyük ateşler yakıp civar köylere mesaj gönderdiğine değinmiştir. Böylelikle çevre köylerin desteği sağlanarak, Fransız ve Ermenilere karşı mücadele başlatılmıştır. Köyde 15 kadına kötülük eden Fransızlar, 2 kadını öldürerek bir hayli hayvanı da imha etmiştir. Köy evlerinin kapılarının kırıldığı, eşyaların yağma edildiği 13 Ocak gecesi çarpışmalar ertesi gün öğlene kadar devam etmiş̧ir. Bu olayla ilgili olarak Müslüman ahaliden bir şehit, iki yaralının olduğunu belirten gazete, Fransızlardan da 100 askerin öldürüldüğünü, Müslümanların 5 askeri ve 2 mitralyözü de ele geçirdiklerini dile getirmiştir.

Maraş şehrinin işgalinden bir hafta önce başlayan bu olaylar karşısında Müslümanlar mecbur kalmadıkça silaha sarılmamış, rahatsızlıklarını protestolarla hükümete müracaat ederek vatanlarının ve canlarının korunması talebinde bulunmuşlardır. Maraş şehrinin işgali ve tecavüzler neticesinde halkın kendisini savunmasının her milletin hakkı olduğuna dikkat çeken gazete “...bu uğurda rahmet-i rahmana kavuşacak dindaşlarımız, yalnız hayatta kalan kardeşlerinin değil, belki bütün 20. asır insaniyetinin hafizayl ihtiramında müebbeden (ömür boyu) yaşayacaktır. Yaptıkları mücahide namus, hayat ve istiklal mücahidesidir. Kahraman Maraşl kardeşlerimize minnet ve muvaffakiyet temini, âlemi İslam'ın bu mücahidata iştirak etmesi müstab'ed (uzak) olmadığını tekrar eyleriz" diyerek bu haklı mücadeleyi izah etmeye çalışmıştır (Hâkimiyeti Milliye, 28 Kânunusani 1336:2).

20 Ocak 1920 tarihinde Salı Günü Maraş’taki Fransız kuvvetlerinin komutanı General Querette, 24 saat içinde hükümet binasının ve Maraş kalesinin teslim edilmesini isteyen bir ültimatomu Türk yetkililere vermiştir. Bu tarih aynı zamanda Hristiyanların Noel tatiline denk gelmiştir. Bu sırada Fransızlar çok miktarda cephaneye sahip olup bunlar, Amerikan binaları, Latin Katolik Manastırı, Ermeni Katolik St. Saviour Kilisesi, Ermeni Protestan Birinci Kilisesi, St. Sarkis Kilisesi, eski Alman yetimhanesinde saklanmıştır. Bir grup asker de çevre kiliselerde hazır bekletilmiştir ( Chorbajian, 1979: 403).

22 Ocak 1920 tarihinde Perşembe günü Maraş’taki Amerikan hastanesine Fransız askerler tarafindan makinalı tüfek yerleştirilmiştir. Türklerin hastaneye saldırmasından endișe duyan Amerikalılar, bu durumdan rahatsızlık duymuşlardır. Bunların başında Dr. Mabel Evelyn Elliott gelmekte olup, Yakın Doğu Amerikan Kadın Hastaneleri Komitesi'nin temsilcisi olarak Maraş’ta 


\section{KSÜSBD Milli Mücadelenin 100. Yılında Kahramanmaraș Özel Sayısı}

bulunmuştur. Olaylar sırasında buradaki Amerikalıların başlıca vazifeleri arasında Fransız ve Ermenileri tedavi etmek, korumak gelmektedir. Bu desteğin yanı sıra Fransız karargâhı ise yaralılar için Amerikan hastanesine sargı bezi göndermiştir. Fransızlar makinalı tüfekler ve toplarını sürekli bir halde kullanırken, Türklerin ellerindeki silahlar yeterli değildir. Maraş Türkleri, Fransız bombardımanı ile püskürtülmüştür (Elliott, 1978: 47-49).

6 Şubat 1920 tarihinde Maraş şehrinde Ermeni ve Fransız kuvvetlerinin saldırısıyla başlayan işgal bütün şiddetiyle devam etmiştir. Ancak büyük fedakârlık gösteren Maraş halkı, şehrin çarşı başı ile Hatuniye mahallesini kısmen düşmandan temizlemeyi başarmıştır. Maraş halkı iki netice üzerine psikolojik olarak odaklanmıştır. Bunlardan biri mukavemet gösterip kurtulmak diğeri ise büsbütün yok olmaktır. İlki üzerinde fedakârlıklarını ve mücadelelerini arttıran Maraş halkının direnci Fransızları telaşa düşürmüştür. Özellikle Ermeniler, çatışmayı saklandıkları kilise, okul ya da evlerden sürdürmeye çalışmış ancak dışarı çıkma cesareti gösterememişlerdir. Şehir, Fransız toplarının saldırısına uğramış, yoğun bir toz bulutu altında kalmış, etraftan şehri kurtarmak için gelen imdat kuvvetleri, düşmanın açtığı top ve mitralyöz ateşine rağmen mücadeleye devam etmiştir. Maraş'ta halkın gösterdiği mücadele Adana ve Urfa'yı da etkilemiş ve oralarda da Kuvâ-yı Milliye'nin teşekkülüne yol açmıştır. Maraş'taki direniş çevredeki büyük aşiretlerin düşmana karşı birleşmesini sağlamıştır (Hâkimiyet-i Milliye, 6 Şubat 1336: 3).

6 Şubat 1920 tarihli “Kahraman Bir Kadın” başlı̆̆ına yer veren gazetede Türk kadınının cesaretine de değinmiştir. Buna göre; Maraş'ın Kayabaşı mahallesinde Bitlis defterdarının hanımının, Ermeni ve Fransızlarca Müslüman kadınlara yönelik çirkin davranışlarına ve tecavüzlerine dayanamayıp evinden açtığı mazgallardan düşmana ateş etmesine, 8 kişiyi öldürmesine ve birçok düşman askerini yaralamasına yer vermiştir. Sabahtan akşama kadar süren çatışmada söz konusu defterdar eşinin, akşam karanlığından faydalanarak erkek kılığında evini terk edip, düşmana karşı halka karışıp cesurca savaşması takdirle karşılanmıştır (Hâkimiyet-i Millîye, 6 Şubat 1336: 4).

Maraş savunmasında etkili olan kadınlardan biri de Senem Ayşe'dir. Senem Ayşe kocasının şehit edilmesi üzerine erkeklerle birlikte Maraş' taki mücadeleye sonuna kadar katılmıştır. Milli Mücadele'ye katılan bu cesur Türk kadınının son yılları ise yoksullukla geçmiştir (Alpaslan, 2015: 20).

1920 yılının Şubat ayının ikinci haftası Maraş'ta çarpışmalar devam etmiş, her taraftan kuşatılmış olan Fransız kuvvetleri, yorgunluk işareti göstermekle birlikte şehrin en hâkim yerlerini ahali ele geçirmeye başlamıştır. Bu durum karşısında Ermeni komitecileriyle Fransiz Generali Querette, Amerikan Kolejine iltica ederek taarruzdan müdafaaya geçmiştir. Fransızların top ateşiyle harabe haline 
gelen şehrin, batı ve kuzey kesimi düşmandan temizlenmiştir. Elbistan, Çardak, Göksun ve çevresinden olmak üzere civar bölgelerden Maraş'a gelen aşiret kuvvetleri düşmanla çarpışmıştır. Bu hareket, Maraş müdafaasının yerel bir hareket olmaktan öte güney bölgesinde genişlemeye başlayan geniş çaplı bir müdafaa hareketi olduğunu göstermektedir. Ahalinin ele geçirmiş olduğu makineli tüfeklerin kullanılabilmesi amacıyla ordudan Maraş' in savunması için firar eden ve Kuvâ-yı Milliye kuvvetlerine katılan askerlerden destek alınmıştır. Gazete 11 Şubat 1920 tarihli "Maraş Müsademesi” başlıklı yazısında “...ahali, Fransizlarl ve onları teşvik etmek suretiyle bu felaketi vücuda getirmiş olan Ermenileri kâmilen imha ve kasabadan tard (kovma) etmeğe muvaffak olmadıkça teslim-i silah etmemeğe yemin etmiştir. Bu kadar kuvvetli bir azim ve imanla hareket eden bir milleti esir edebilecek kuvvet yoktur. Şüphesiz Fransizlar da bunu bilirler" denilerek Maraş halkının azim ve kararlığı ortaya konulmuştur. Gazete devamında "eğer General Querette şehrin Fransizlar tarafindan terki, Hristiyan ahalinin kâmilen katliamina sebebiyet vereceğinden korkuyor ve müsademeyi ( çarpışma) böyle bir hiss-i himaye ile devam ettirmeğe mecbur görüyorsa Fransız kuvvetinin oradan çekilmesi kararlaştırlldıktan sonra hükümete müracaat etmek suretiyle bu meselenin halli mümkündür” şeklinde bir çözüm alternatifi de sunmuştur (Hâkimiyet-i Milliye, 11 Şubat 1336: 2).

Hâkimiyeti Milliye gazetesi, Maraş'ın Fransızlarca işgali ve Ermenileri gözetip hainliklerine göz yummasını eleştiren yazılar yazmasının yanı sıra kendi toprağında yabancı işgaline uğrayan Türk milletinin haklı mücadelesini de duyurmaya çalışmıştır. Ancak yabancı basın, bu olayı çarpıtarak Türkleri zülüm eden bir millet olarak göstermiş ve İtilaf devletlerinin işgallerine kendilerince haklı gerekçeler bulmaya çalıştıklarını belirtmiştir. Bu kapsamda The Armenian Review, Fransızları Ermenilere yeteri kadar destek vermemekle suçlarken Ermenileri masum ve Türkleri ise cani, insafsız göstermeye çalışmıştır. Bununla ilgili olarak “...ah bu zulümlerin intikamını almak için can atan, çoğu Amerika'daki evlerinin rahatlığını terk eden ve ailelerinden să̆ kalanlarını bulmayı umut ederek orduya katılan talihsiz lejyonlardı. Fakat yazlk! Şimdi kalleş Fransız diplomasisinin amaçlarının kurbanı oluyorlar... ” Yine söz konusu dergi, 4 Şubat 1920 Çarşamba günü yaşanan olaylara istinaden “...böylece 15 günlük savaştan sonra şehirde Ermeni kalmadı. Bugüne kadar 3.000 Ermeni öldürüldü ve să̆ kalan 18600 Ermeni yedi ya da sekiz garnizona sığındı... Ermeniler kaçtıklarında aç ve çıplaktı. Yatakları yoktu. Evleri... Erzakları, mobilyaları yoktu" ş̧eklinde yayınlara yer vermiştir (Chorbajian, 1979:407-408).

Hâkimiyeti Milliye gazetesi, Maraş'ın işgali hakkında yer yer verdiği haberlerin başında Fransızların, Ermenileri şımartarak Müslüman halkın canına, ırzına yapılan insanlık dışı vahşetin medeni bir ülke iddiasında olan Fransa'nın kendisiyle çeliştiğine dikkat çekmiştir. Müslüman halkın katledilmesi yalnızca Maraş'ta değil aynı zamanda Diyarbakır, Harput, Malatya mıntıkalarında 


\section{KSÜSBD Milli Mücadelenin 100. Yılında Kahramanmaraș Özel Sayısı}

Ermenilerce devam ettirilmiştir. Şubatın başında İngiliz ve Fransızlardan oluşan bir heyet, Cerablus'a gidip bölge aşiretlerinin desteğini istemiştir. Cizre'de toplanan 16 aşiret reisi, Amerikan Başkanı Wilson'a bir telgraf çekerek Osmanlı idaresi dışında başka bir idare tanımadıklarını, bütün kuvvetlerini vatan uğrunda birleştirmeye kararlı olduklarını belirtmiştir (Hâkimiyet-i Milliye, 16 Şubat 1336: 2-3).

Şubatın sonlarına gelindiğinde Maraş'tan Fransızların çekildiklerini görmekteyiz. Bu çekiliş sonrası şehirde asayiş sağlanmışsa da geriye her haliyle harap bir şehir kalmıştır. Halk, şehrin kurtulmasına sevinmekle birlikte 20 gün aralıksız devam eden çarpışmalar, yaşanan vahşetin büyük yıkıntısı altındadır. $\mathrm{Bu}$ zamana kadar ahaliden 200 şehit, 500 yaralı olmakla birlikte uçları kesik kurşunlarla yaralanmış olan vatan evlatlarının durumu ise ağırdır. Yaralılar, şehrin batı ve doğu bölgelerinde açılan 2 hastaneye gönderilmekte ve tedavileri oralarda yapılmaktadır. Maraş'taki yaralıların tedavisi noktasında Amerika Salibi Ahmer Heyeti'nin de katkısı olmuştur.

Latin Kilisesi Reisi, Ermeni milletinden Çorbaciyan, Ermeni Murahhas1, Ermeni Katolik Murahhası Avadis, Ohannis Muradyan, Ser rahip Kredkiyan gibi Ermenilerden oluşan kanaat önderleri tarafından Dâhiliye Nezaretine, Patrikhaneye ve İtilaf devletleri temsilcilerine birer telgraf çekilmiştir. Söz konusu telgrafta; Maraş'a Fransızların gelmesi üzerine zorla hane ve kiliseleri işgal ettikleri, bazı Ermeni gençleri silah zoruyla tehdit ederek Türklere karşı kötü davranmaları talep edildiği, Türklerle iyi ilişkileri olanların ise hapis edildiği ve binlerce Ermeni’nin kanına girildiğinden bahsedilmiş̧ir. Gazetede belirtildiğine göre Maraş'tan çekilen Fransız askerlerinden 200'ü halk tarafından öldürülmüştür. Bu çekilişten sonra en büyük sorun harap haline gelmiş Maraş’1 eski günlerine döndürmek olmuştur (Hâkimiyet-i Milliye, 21 Şubat 1336: 3).

\section{Hâkimiyet-i Milliye Gazetesine Göre Ermeni Mezalim Örnekleri}

Mütareke sonrası Anadolu'da başlayan itilaf kuvvetlerinin işgalleri Maraş, Ayıntap, Urfa ve Kilis'e de sıçramıştır. Bu sırada hunharca Fransız-Ermeni işbirliğince gerçekleştirilen işgallerde genç, masum Türk çocukları süngülenmiş̧ir. Maraş’taki kızların can ve namuslarına kötülük yapılmıştır. $\mathrm{Bu}$ şehirdeki 40 Müslüman kadın hamamdan çırılçıplak çıkarılarak esir edilmiştir. Müslümanların derileri soyulmuş, uzuvları koparılmıştır. Maraş’ta kış ayına denk gelen işgal neticesinde evsiz barksız kalan kadın ve çocuklar çamurlar içinde aç ve perişan halde ölüme terk edilmiştir. Fransızlarca silahlandırılan Ermeniler her firsatta Müslüman ahaliye kötülük yapmaktan geri durmamıştır (Hâkimiyet-i Milliye, 3 Mart 1336: 3). 
Söz konusu gazete, Maraş'ta Ermenilerin halka yaptığı mezalimlerden örneklere de yer vermiştir. Bunların arasında Himmet çavuş isimli bir Türk’ün gündüz vakti bir Ermeni tarafından öldürülmesi sonrasında olayla ilgili her hangi bir incelemenin yapılmadığı belirtilmiştir. Mezkûr olayda Türkü öldüren Ermeni gencinin, Ermeni komiteleri tarafindan 300 lira ile ödüllendirildiğine yer verilmiştir. Kasaba civarında bağ bekçilerinden ve Rumeli muhacirlerinden 4 Müslümanın, 5 Ermeni tarafindan kâma ve kasaturayla boğazlandığı, 3'ünün öldüğü, birinin durumunun çok ağır olduğu haberde verilen bir başka örnektir. Bunun yanı sıra kasaba civarında bağlarına gitmekte olan Topal Hacızâde Ahmet ile biraderi Mustafa Efendi ve Kürt Ahmet Çavuş̧un öldürülmesi üzerine cenazelerin alınabilmesi için Mösyö Tayarde'ye birçok kez müracaat edildiği belirtilmiştir. Bir başka olaya yer veren gazete, Cemal Çavuş’un zevcesinin ormana götürüldükten sonra tecavüze uğrayarak öldürüldüğüne, gündüz kadın ve erkeklerin durdurulup araştırma yapılacağı bahanesiyle insanların paralarının ellerinden zorla alındığına, Müslüman evlerin kapılarının silahlı Ermenilerce kırılıp eşyaların talan edildiğine yer vermiştir. Kıymetli eşyaları alınan köylülerin öldürülerek, köylerinin ateşe verilmesi Maraş halkının maruz kaldığı facialardan yalnızca bir kaçıdır (Hâkimiyet-i Milliye, 20 Mayıs 1336: 3).

Kara Ali Çavuş ve üç arkadaşıyla Pazarcık'ın Akça Koyunlu köyünden Antep'e giderken yolda Fransız elbisesi giymiş olan on beş silahlı Ermeni tarafindan feci bir şekilde öldürülmüsslerdir. Fransızlar, Ermenileri silahla, fedailerini de bombalarla donatmış ve geceleri kahvehanelere bombalar atılarak birçok Müslümanın şehit olmasına ya da yaralanmasına yol açmışlardır. Maraş Mutasarrıflığından Fransızlara yapılan tüm başvurular sonuçsuz kalmıştır. Fransız işgal kuvvetleri sürekli takviye edilmiş ve Müslümanlar, Ermenilerin zalimce saldırılarına ve Fransız kuvvetlerinin baskılarına maruz kalmışlardır. Maraş ve çevresindeki Ceceli köyü Ermeni çetesi tarafindan yakılıp yıkılmıştır. Fransız müfrezesi tarafindan Karabıyıklı'dan gelmekte olan Jandarma Ali Çavuş katledilmiştir. Fransız askerlerince Maraş'ta ikamet eden Ahur dağı civarında köylerine giden iki Müslüman süngülenmiştir. Fransızlar tarafindan Maraş Ermenileri açıkça silahlandırılmış ve devamlı olarak mühimmat, top ve silah toplatılarak Ermeni evleri müstahkem bir mevki haline getirilmiştir. Tüm bu hazırlıklar, Fransızların himayesindeki Ermenilerin, Müslümanlar aleyhine bir katliam tertibi içinde olduklarını göstermektedir (Başbakanlık Devlet Arşivleri Genel Müdürlüğü Osmanlı Arşiv Daire Başkanlığı, 2003: 19-26).

Maraş’tan Fransızların çekilmesi hakkında gazetenin bildirdiğine göre; 200 Fransız askeri öldürülmüştür. Bu çekilişten sonra en büyük sorun harap haline gelmiş Maraş'1 eski günlerine döndürmek olmuştur (Hâkimiyet-i Milliye, 21 Şubat 1336: 3). 


\section{KSÜSBD Milli Mücadelenin 100. Yılında Kahramanmaraș Özel Sayısı}

Fransızlar, 11 Şubat 1920 tarihinde Maraş'1 terk etmek zorunda kaldıklarında Ermenilerin bir kısmı onlarla gitmiş, geriye kalanlar ise Amerikan misyonerlerine sığınmışlardır. 10.000 kadar Ermeni ise canlarına dokunulmadan, güven içinde yaşamlarını sürdürmüşlerdir. Fransızların yeni kurulan Türk devletiyle imzaladıkları Ankara Anlaşması gereğince bölgeden ve tüm Çukurova'dan çekilmeleri üzerine Ermeniler, Maraş’tan ayrılmaya karar vermişlerdir. Böylece Maraş'ta kalan son Ermeniler, Amerikalı misyonerlerin gözetiminde gruplar halinde 1922 Ocak'ına kadar şehirden ayrılarak Beyrut'a, İstanbul'a ve Avrupa'ya gitmişlerdir (Dinçaslan, 2009: 29-30).

\section{Sonuç}

Hâkimiyeti Milliye Gazetesi, Milli mücadele döneminin başlangıç safhasını oluşturan Güney Cephesi ve bu cephenin içinde yer alan Maraş bölgesindeki Fransız-Ermeni zulmünü yakından takip ederek gelişmeleri okurlarıyla buluşturması bakımından büyük bir öneme haizdir.

Gazete, Maraş şehrinin Fransızlarca işgali neticesinde Kuvâ-yı Milliye ruhunun nasıl teşekkül ettiğini ortaya koyarken, mümkün mertebe FransıErmeni zulmüne karşı ilk yolun Osmanlı hükümeti, İtilaf kuvvet ve devletlerine çekilen protesto telgraflarıyla olduğunu belirterek Türklerin barışçıl bir yol izlemekten yana bir eğilim içinde olduklarını göstermeye çalışmıştır. Ancak işgal kuvvetlerinin ve Ermenilerin Maraş'taki katliamları, tecavüzlerini devam ettirmeleri üzerine Fransa'nın bölgede izlemiş olduğu politikalar eleştirilerek halkı uyarma ve uyanık davranmaya davet etmiştir. Maraş halkının ve çevre köylerdeki aşiretlerin, Fransız işgaline yönelik direnişi başta Adana ve Urfa olmak üzere işgale uğramış şehir ve köylerdeki Türk milletine sirayet etmiştir. Böylelikle sayıca ve askeri teçhizat bakımından kuvvetli Fransız ordusu karşısında bağımsızlık ateşi içinde hareket eden bir milli bir ruh ortaya çıkmıştır.

Hâkimiyet-i Milliye Gazetesi'nin haberlerinden de anlaşılacağı üzerine Maraş'ın işgali süresince gerek Fransızlar gerek Ermeniler, şehirde bulunan Amerikan misyonerleri ve okullarından açık destek almışlardır. Gazete, Maraş halkının işgale karşı vermiş olduğu haklı mücadelesinde Türk kadınını da unutmamıştır. Adını bilmediğimiz Bitlis defterdarının eşinin ve Senem Ayşe'nin, Maraş'ın düşman işgalinden kurtuluşu için yaptıkları fedakârlıkları da dile getirmiştir. Bu tarz haberler üzerinden Türk kadınının, düşman işgali karşısında kayıtsız kalmadığı ve vatan savunmasında tüm milletin ortak bir duygu etrafinda birleştikleri ifade edilmiştir. Gazete, haberlerinde bölgedeki Ermenilerin bir kısmının söz konusu işgaller karşısındaki rahatsızlıklarına değinmiş, Türklerle iyi ilişkiler içinde olan Ermenilerin baskı gördüklerine ve tehdit edildiklerine de yer vermiştir. 
Hâkimiyet-i Milliye Gazetesi'nde belirtildiğine göre Fransızlar tarafindan Ermenilere verilen tam destek Maraş halkının büyük bir direnç göstermesi neticesinde azalmış ve 22 gün süren mücadele sonunda düşman geri çekilmek zorunda kalmıştır. Gazete, haberlerinde manevi değerlere de yer vererek halkın direnme gücünü arttırmayı amaçlamış ve Türk milletinin bağımsızlık azmini her daim kuvvetlendirme yoluna gitmiştir.

\section{KAYNAKÇA}

\section{1-Süreli Yayınlar}

Hâkimiyet-i Milliye 3 Mart 1336, 6 Şubat 1336, 11 Şubat 1336, 16 Şubat 1336, 21 Şubat 1336, 24 Şubat 1336, 28 Kânunusani 1336, 10 Kânunusani 1336, 20 Mayıs 1336

\section{2-Kitap ve Makaleler}

Akbıyık, Yaşar (1999), Milli Mücadelede Güney Cephesi Maraş, Atatürk Araştırma Merkezi Yay., Ankara

Alpaslan, Erhan (2015), “Milli Mücadele Dönemi’nde Anadolu'da Kurulmuş Olan Kadın Derneklerinin Maraş Milli Mücadelesinde Destekleri”, Milli Mücadelede Güney Bölgesi Sempozyumu,25-27 Aralık, Gaziantep 2013, Atatürk Araştırma Merkezi, Ankara, ss.3-24.

Armaoğlu, Fahir (2007), 20. Yüzyıl Siyasi Tarihi, Alkım Yay., İstanbul.

Büyükoğlu, Yaşar (2012), Milli Mücadele Döneminde Güneydoğu Anadolu, Ekin Yay., Bursa.

Chorbajian, Ghevont (1979), “The 22 Days of Marash: Papers on the Defense of the City Against Turkish Forces Jan.-Feb., 1920 (Part III): A Diary of the Events in Marash", The Armenian Rewiev, Vol. 31, No. 4-124, April, ss.402-417.

Dinçaslan, Latif (2009), “Zeytun'da Misyoner Faaliyetleri”, Erciyes Üniversitesi-Nevşehir Üniversitesi II. Uluslararası Sosyal Araştırmalar Sempozyumu (EUSAS-II), 22-24 Mayıs 2008, Hoşgörüden Yol Ayrımına Ermeniler, Cilt: 3, Erciyes Üniversitesi Yay., ss.9-32.

Doğan, Ayhan (2004), Çanakkale'den Cumhuriyet'e Maraşlı Şehitler I, Berikan Yayınları, Ankara. 
Doğan, Orhan (2011), “ Milli Mücadelede Sebîl'ür-Reşad Dergisi ve Eşref Edib'in Maraş Ve Ayntablıların Kahramanlıkları", Gaziantep Üniversitesi Sosyal Bilimler Dergisi, 10 (4), ss. 1439-1474.

Doğan, Orhan (2008), “İngiliz ve Fransız İşgali Altındaki Maraş’ın Kurtuluş Mücadelesi (Önemli Olaylar / Öne Çıkan İsimler)", Maraş Tarihi ve Sanatı Üzerine, Kahramanmaraş Sütçü İmam Üniversitesi Yayınları, Kahramanmaraş, ss. 251-274.

Elliott, Mabel Evelyn (1978), “The 22 Days of Marash: Paper on The Defense Od The City Against Turkish Forces Jan-Feb., 1920", Armenian Review, Volume: 31, No: 1-121, Spring, ss.47-64.

Eyicil, Ahmet (2015),“İşgal Döneminde Fransız ve Ermenilere Karşı Maraş Mücadelesi”, Milli Mücadelede Güney Bölgesi Sempozyumu, 25-27 Aralık, Gaziantep 2013, Atatürk Araştırma Merkezi, Ankara, ss.57-81

İlter, Erdal (1995), Türkiye’de Sosyalist Ermeniler ve Silahlanma Faaliyetleri (1890-1923), Turan Yay., İstanbul.

Mütercimler, Erol (2010), Gelibolu 1915, 11. Basım, Alfa Yayınları, İstanbul.

Oran, Baskın (2009), "Mondros Silah Bırakışması”, Türk Dış Politikası (19191980), Editör: Baskın Oran, C: I, İletişim Yay., İstanbul.

Osmanlı Belgelerinde Ermeni- Fransız İliş̧kileri (1920-1922) (2003), Başbakanlık Devlet Arşivleri Genel Müdürlüğü Osmanlı Arşiv Dairesi Başkanlığ 1 , Cilt: III, Ankara.

Özkan, Kenan (2016), Milli Mücadele Dönemi Türkiye-ABD İlişkileri 19181923, Ötüken Yay., İstanbul.

Özkan, Salih (2015), “Albayrak Gazetesine Göre Maraş Savunması”, Milli Mücadelede Güney Bölgesi Sempozyumu, 25-27 Aralık, Gaziantep 2013, Atatürk Araştırma Merkezi, Ankara, ss.129-145.

Özkaya, Yücel (2007), Milli Mücadele’de Atatürk ve Basın, Atatürk Araştırma Merkezi Yay., Ankara.

Hatipoğlu, Süleyman (2001), Türk-Fransız Mücadelesi (Orta Toros Geçitleri, 1915-1921), Atatürk Araştırma Merkezi Yay., Ankara.

Ünalp, F. Rezzan (2018), "Birinci Dünya Harbi Sonunda Maraş'ın İtilaf Devletlerince İşgali ve Maraş Savunması”, Akademik Bakış, Cilt: 11, Say1: 22, ss. 205-235. 
"The 22 Days of Marash: Paper on The Defense Od The City Against Turkish Forces Jan-Feb., 1920" (Winter 1977-78), The Armenian Rewiev, Vol. 30, No: 4-120, ss.383-397.

Turan, Şerafettin (2008), Mustafa Kemal Atatürk Kendine Özgü Bir Yaşam Ve Kişilik, 2. Basım, Bilgi Yayınevi, Ankara. 